Bowes, A., \& Bairner, A. (2018). England's proxy warriors? Women, war and sport. International Review for the Sociology of Sport, 53(4), 393-410. https://doi.org/10.1177/1012690216669491

\title{
England's Proxy Warriors? Women, War and Sport
}

Ali Bowes and Alan Bairner

\section{Abstract}

It has been claimed that the one place Englishness exists in on the sports field (Robinson, 2008), and often it is men's sport that appears central to creating a sense of English national identity (Tuck, 2003). However, in light of England's recent sporting success across multiple women's sports (namely cricket, netball, association football and rugby union), there warrants a need to begin to question the place of these women in discussions of the nation (Bairner, 2015). Drawing on extensive interview data with women who have represented England at sport, this paper seeks to 'give a voice' to these women whose experiences have often been ignored by both the popular press and academics alike. This research discusses the way in which English women represent their nation, both on the field of play and more broadly, and sheds light on the complexity of the intersections of gender and national identity. It is argued that, through playing international, representative sport, the women actively embody the nation, with national identity often overriding gendered identity in these instances. In this sense, they become proxy warriors for the nation.

Key words: National identity, Englishness, gender, women

\section{Introduction}

Many authors on the relationship between sport and national identity highlight that the nation appears to become more 'real' in the domain of sport, on the terraces or on the athletics tracks (Jarvie, 1993). Harris and Clayton (2007: 209) argue that Anderson's (2006) concept of an 'imagined community' is, 'in many cases, (re)created through sport'. However, the sport that is central to recreating the national imagined community is often considered a male-only domain. Hobsbawm (1990: 143) himself concluded that 'the imagined community of millions seems more real as a team 
of eleven named people', although it is hard to conceive he thought those eleven people were anything other than men. He argued that sport, at least for males, has proved 'uniquely effective' in generating a sense of belonging to the nation. Thus, these national sporting teams, composed of the best players born within certain national boundaries (or those who qualify by other means to represent a particular nation) become the focus for powerful, if unrealisable, fantasies. This whole approach clearly implies a gendered relationship between sport and nationalism, identifying the national sporting arena as one that is constructed by men, for men.

Sport undeniably provides us with an ideal framework for studying national identity, as exemplified in its use by scholars investigating the idea of English national identity (see Malcolm, 2009; Polley, 2004; Robinson, 2008). Of course, the complex relationship between England and Great Britain, as well and England and the other 'home nations', is well documented (e.g. Aughey, 2007; Kumar, 2003 CHECK). The Scottish independence referendum in 2014, and the EU referendum in the United Kingdom in 2016 further highlighted the complexity of national identities on what are often contentiously referred to as the British Isles. This is also highlighted in the sporting realm. For example, it is only in exceptional cases where nation-state representation is required by international organisations, such as the International Olympic Committee, that representatives of the constituent nations of the United Kingdom compete under the flag of Team GB. In other contexts, and specifically in sports so often associated with England and Englishness, such as cricket, association football, and rugby union, England competes as a separate nation. But what sense of Englishness does this convey, particularly in the minds of national sporting representatives?

The summer of 2015 was an interesting time for women's sport in England. The rugby union squad won a world title, following a 21-9 victory over Canada on 17th August 2015. The women's football team showcased their talents at the 2015 FIFA Women's World Cup in Canada, narrowly losing to a stoppage time own goal against Japan in the semi-final, before collecting their bronze medals after victory over Germany in the 3rd/4th play-off game. This represented the best finish by an England senior team since the men won the 1966 World Cup at Wembley. England's netballers also picked up a bronze medal in the 2015 Netball World Cup in Sydney, while the cricketers finished runners up in the 2014 ICC Women's World Twenty20.

However, although these women's successes were celebrated across England, there were timely reminders of the positioning of women, not only in the national sporting arena, but also more generally within the nation. Nowhere was this highlighted more than in a message posted on social 
media website Twitter by the Football Association, following the women's football world cup. The 'tweet' stated: 'our lionesses go back to being mothers, partners and daughters today, but they have taken on another title - heroes' (Bates, 2015). Such comments contrast markedly with the way in which male athletes are perceived in the media as proxy warriors for their respective nations. Bairner (2015) asks, are men alone the proxy sporting warriors or can women also fulfil this role and, if so, within which sports and in which countries? Responding to Bairner's (2015) call to learn how international sporting women themselves see their status in relation to the national project, we present data retrieved from interviews with England's female national sporting representatives and situate their views within wider of debates about gender, war and nationhood.

\section{Sport, the Nation and War}

Considering the nation in relation to sport requires an initial understanding of what nations and nationalism are and what connects them. Linking nationalism closely to statehood formation, McCrone (1998: 10) argues that 'nationalism is a cultural and political ideology of "modernity", a crucial vehicle in the great transformation from traditionalism to industrialism, and in particular the making of the modern state'. More generally, however, modernists believe that nationalism is a social construction, emerging around the time of the political and economic revolutions of the eighteenth century. Hobsbawm's (1983) theory of 'invention of tradition' and Anderson's (2006) work on 'imagined communities' have been central in debates surrounding the nation.

Anderson (2006) believed that 'all communities larger than primordial villages of face-to face contact are imagined' (2006: 6). His argument is that members of large communities will almost certainly never have direct contact everyone in that community, yet they perceive themselves to be connected to them. He states, 'societies are sociological entities of such firm and stable reality that their members can even be described as passing each other on the street, without ever becoming acquainted, and still be connected' (ibid: 25). Hobsbawm's (1983) work on invented traditions discussed 'traditions' which appear or are claimed to be old, but are in fact often quite recent in origin, and sometimes invented. He states that 'invented tradition' is thus a 'set of practices, normally governed by overtly or tacitly accepted rules and of a ritual or symbolic nature, which seek to inculcate certain values and norms of behaviour by repetition, which automatically implies continuity with the past' (ibid: 1). For Hobsbawm, national flags, images, ceremonies and music are historically novel and largely invented. It is this linking of national symbols with practices which aids the development of an 'invented tradition'. Indeed, work on national identity and sport has often 
employed, for analytical purposes, both Anderson's (2006) imagined communities and Hobsbawm's invented traditions (see Lechner, 2007; Maguire and Poulton, 1999).

According to Robinson (2008: 219), 'England exists more in imagination than it does anywhere else'. If this is true then sport is essential in the imagining the English nation, as it is one of the few places in which the English nation appears 'real'. Robinson (2008: 219) claims that it has become increasingly apparent that 'the one place where England exists is on the sports field'. National sports teams embody the nation. As Smith and Porter (2004: 2) suggest: Having once made the requisite leap and accepted that the eleven men who appear in white shirts at Wembley, or the fifteen at Twickenham, are 'England', the possibilities for defining and redefining what it means to be 'English' are inextricably linked to what happens on the field of play. For the ninety minutes of football, eighty minutes of rugby, or even five days of cricket, those men on the field of play represent England and make it seem 'real'. These players represent 'their' countries as highly visible embodiments of these nations and become 'patriots at play' (Tuck and Maguire, 1999). Not only that, the pride and patriotism evoked during their sporting contests can be likened, in certain respects, to those experienced within the context of war (Tuck and Maguire, 1999).

War and (men's) sport have often been linked by both the media and academics alike. For Bairner (2001), sport and war represent two of the most emotive issues in the modern world, with the sense of nationhood and community between strangers during war times equalled only during major sporting events. George Orwell's proposal in 1945 that that 'sport is war minus the shooting' (cited in Orwell and Angus, 1970) highlights the way in which sport 'is bound up with the rise of nationalism - that is, with the lunatic modern habit of identifying oneself with large power units and seeing everything in terms of competitive prestige' (Orwell and Angus, 1970: 63). This linking of (men's) sport and war is strengthened by the role of the popular press, with Jansen and Sabo (1994) highlighting how both the language of sport and the language of war represent central values of hegemonic masculinity, such as aggression, competition, dominance, as desirable. Bairner (2001: 177) states, Bearing in mind Hoberman's (1984) description of sports people as 'proxy warriors', the fact is that, throughout the twenty-first century, sport has been one of the most valuable weapons at the disposal of nationalists, whatever their situation or respective aspirations. In addition, if sport can be likened to war, then, as we have seen, it is likely that male athletes become the proxy warriors. So where do women fit into this debate? As Chiang et al (2015) emphasise, debates around sport and nationalism, as well as sport, the nation and warfare have tended to almost exclusively feature men, thereby leaving women on the margins, despite the fact that there is a significant literature on the relationship between women and war. 


\section{Writing Women into War, the Nation and Sport}

Whitehead et al (1993: 1) explain that 'nationalism is gendered - women's bodies are the boundary of the nation, and the bearers of its future.' The construction and naturalization of gender differences have an impact on every area of social life and, consequently, there is no reason to believe that the social organization of nations and nationalism is exempt from their influence (Day and Thompson, 2004). Similarly, for McClintock (1993: 61), 'all nations depend on powerful constructions of gender', and despite the idea of 'popular unity, nations have historically amounted to the sanctioned institutionalization of gender difference' (original emphasis).

Despite all of this, Nira Yuval-Davis (1997), who has been central in feminist interpretations of nationalism, outlines how most hegemonic theorizations about nations and nationalism have treated gender relations as irrelevant. Leading theorists of nations, such as the aforementioned Anderson and Hobsbawm, while mentioning gender in their works, have failed to elaborate on its importance (McCrone, 1998). Pettman, however, (1996: 187) explains how the gender politics of nations and nationalism are complex, 'including both the gendering of the nation as female and the construction of women as mothers of the nation, responsible for its physical, cultural and social reproduction'. Women's roles in the nation are often linked to their reproductive ability; thus, Yuval-Davis and Anthias (1989) identify five ways in which women have participated in national and nation-state processes and practices:

1. as biological reproducers of members of ethnic collectivities;

2. 2. as reproducers of the (normative) boundaries of ethnic/national groups;

3. 3. as participating centrally in the ideological reproduction of the collectivity and as transmitters of its culture;

4. 4. as signifiers of ethnic/national differences;

5. 5. as participants in national, economic, political and military struggles.

This framework highlights not only the practical but also the symbolic nature of women's national positioning. However, as Nagel (2008: 900) contends, 'the idea of the nation and the history of nationalism are intertwined with the idea of manhood and the history of manliness'. The close association established in the men-nation-war nexus means that both the nation and war are typically seen as male domains. Furthermore, it is equally apparent that modern sports have been powerful sources of male imagery, rendering women's involvement problematic. 
Like the nation, according to Messner and Sabo (1990: 9), sport is 'an institution created by and for men' which orientates itself according to male values and norms, to the extent that, throughout history, women's struggles to participate in sport and be accepted as athletes has been constantly evident (Hargreaves, 1994). Despite the changing landscape of women in sport over the past halfcentury, Adams (2017) highlights that sport remains an institution dominated by men, and rife with discriminatory practices. For Theberge (1994: 185), 'the ideological process that legitimizes women's sporting experience begins with the general belief that the sexes are innately different and that males are superior'. Sport is often considered a legitimate place for the demonstration of this superiority. Whilst these statements may seem outdated, as Matthews (2016) argues, in general sport continues to provide an avenue for the demonstration of a socially constructed form of masculinity, in opposition to which femininity, equally socially constructed has traditionally been defined. On the whole, sport, as a symbol of male power and privilege, has served to consolidate mainstream gender expectations of men and women alike, situating femininity in opposition not only to masculinity but also to athleticism.

While sport appears to maintain the binaries of both sex and gender, various theorists have moved to look at gender in more multiple, fluid ways. For example, we have Judith Butler's refutation of the idea that categories of sex, gender and desire are natural rather the products of particular power formations. For McLaren (2002), Butler's performative theory of gender illustrates the way in which these categories are produced and maintained through a variety of social practices including sport. Butler (1990) challenges those distinctions between sex and gender which see sex as the biological basis upon which gender is simply inscribed. Instead gendered subjectivity is acquired through repeated performance by the individual of discourses of gender. Thus rather than being a gender, we 'do' a gender. Butler (1990: 25) notes that 'gender proves to be performance - that is, constituting an identity it is purported to be', thus gender is an act that brings into being what it names - masculine men or feminine women.

In a sporting environment, the term feminine is often considered to be synonymous with heterosexual (Hall, 1996). Compulsory heterosexuality acts as a form of social control through the normalization and naturalization of heterosexuality (Scraton and Flintoff, 2013). This point is emphasised by Caudwell (1999) who identifies a hierarchy of sexuality, with heterosexuality as the norm and homosexuality as a deviant form of behaviour. Caudwell (2003) further explored the compulsory order of sex-gender-desire (for desire read sexuality) in sport and highlighted the operation of a woman-feminine-heterosexual nexus, with the body as a site/sight for anchoring this lineage, and explained how women's bodies are disciplined by the woman-feminine-heterosexual 
order that supports sport's system of sex-gender differentiation. Caudwell (2003: 384-385) argues that 'regulatory practices attempt to materialize women's sporting bodies through a compulsory ordering of woman-feminine heterosexual'.

Due to the compulsory order of woman-feminine-heterosexual, female athletes are often under pressure to look feminine and display feminine behaviour in order to compensate for their 'unfeminine' actions when playing sport. Subsequently, Hargreaves (1994: 169) noted that 'women athletes feel the necessity to conform to dominant images of heterosexual femininity because female muscularity is treated as a sign of masculinisation'. As Cox and Thompson (2000: 10) explain, 'female athletes, who deviate from the 'norms' of femininity by having...athletic bodies, are challenged overtly or covertly about their sexuality'. With all of this in mind, Halberstam (1998) introduced the term 'female masculinity', which prises away masculinity from its close association with men. However, the continued stigmatization of athletic women helps to maintain sport as a male domain. In addition, and of particular relevance to the present study, the labelling of sportswomen as homosexuals further problematizes the relationship of the nation's women (as reproducers) to both sport and warfare.

Adams (2017) draws attention to the way in which sport has become a legacy of second wave feminism, with more women participating in a broad range of sports than ever before. Indeed, women continue to make inroads into traditional male sports and, in so doing, actively redefine readings of women's sports by blurring the boundaries between the traditional binary of masculinity and femininity. Hargreaves (1994: 161) proposes that the female athletic body can be 'a symbol of empowerment and an escape from the traditional images of femininity and domesticity', despite Dworkin's (2002) proclamation of a 'glass ceiling' on women's muscular strength. How far, though, if at all, has society come in accepting and celebrating women's participation and achievements in sport? Willis (1994: 35) questions how it is that 'the meanest local fifth division, male works' team gets more respect, in popular consciousness, than a women's national team'. Although there is plenty of evidence to support this way of thinking, what sportswomen themselves think about their status as women, athletes, and representatives of the nation has largely been ignored.

\section{Methodology}

The relationship between women, the construction of nations, and the reproduction of national identities remains generally under researched. Likewise, women have been systematically excluded from literature on sporting nationalisms, and as a result, their experiences have seldom been directly addressed. Much of the research that is concerned with national identity in sport utilizes a 
methodological approach which analyses the role of the media in (re)producing a sense of national identity (e.g. Tuck, 2003; Wensing and Bruce, 2003). However, few research studies actually focus on those who embody the nation in sport - namely, the athletes themselves. This is confirmed by Holmes and Storey (2004: 95) who write, 'little research into professional sportspeople's attitudes to issues of national identity has been undertaken'. However, when such research has been conducted, the athletes in question have tended to be men (Tuck and Maguire, 1999; Tuck, 2003; McGee and Bairner, 2011).

\section{Participants}

Amis (2005: 105) explains that interviews offer a depth of information that permits a detailed exploration of particular issues, as the interviewer 'attempts to gain insight into the inconsistencies, contradictions and paradoxes that are a quintessential part of our daily lives'. As such, this paper draws upon data taken from a series of semi-structured interviews conducted with English sportswomen from cricket, association football, netball and rugby union in 2011-12 (see Table 1), as part of a wider study. The sports were carefully selected; in these sports, unlike others, there is not usually a team that is representative of Great Britain (except for the unique situation of a Team GB women's football team at the 2012 Olympics). It was felt that this experience of being identified as English by way of their sporting representation would give the participants a unique view of English national identity and its separation from Britishness.

Table 1

\begin{tabular}{lll}
\hline Name & Sport & $\begin{array}{l}\text { International Appearances (at } \\
\text { time of interview) }\end{array}$ \\
\hline Claire Allen & Rugby Union & 24 \\
\hline Charlotte Barras & Rugby Union & 48 \\
\hline Tammy Beaumont & Cricket & 13 (7 ODI \& 6 T20) \\
\hline Sophie Bradley & Association Football & 10 \\
\hline Katherine Brunt & Cricket & 89 (7 Test, 58 ODI, 24 T20) \\
\hline Dani Buet & Association Football & 7 \\
\hline Karen Carney & Association Football & 60 \\
\hline Stacey Francis & Netball & 13 \\
\hline Serena Guthrie & Netball & 7 \\
\hline Kerys Harrop & Association Football & 25 (U19/U20/U23) \\
\hline
\end{tabular}




\begin{tabular}{lll}
\hline Harriet Millar-Mills & Rugby Union & 9 (U20) \\
\hline Beth Morgan & Cricket & 107 (7 Test, 72 ODI \& 28 T20) \\
\hline Olivia Murphy & Netball & 95 \\
\hline Claire Purdy & Rugby Union & 28 \\
\hline Claire Rafferty & Association Football & 5 \\
\hline
\end{tabular}

As elite level athletes were the subject of this research, it was essential to identify a number of gatekeepers before full contact could be established with all participants (McGee and Bairner, 2011). This was aided by the location of the University in which the research took place, As the UK's premier sporting university, Loughborough has numerous female alumni who have gone on to gain full representative honours for England. The women with whom the first author initially made contact were able to pass on information about friends and the resultant snowballing effect led to the composition of the participant base. As Seale and Filmer (1998: 139) explain, 'this can be a very helpful way of gaining access to people who, without such a personal contact, might otherwise refuse to be interviewed'. Snowball sampling, although contradictory to many underlying assumptions about sampling (often linked to positivist notions of reliability and validity), has a number of advantages for studying populations such as elites (Atkinson and Flint, 2003).

Atypically, the participants in this research project are identifiable due to their visibility as elite, international level, sport participants. After consultation with the University ethics committee, and following McGee and Bairner (2011), it was decided to make a virtue of this and feature the interviewees as themselves in the research, named, and contextualized with personal details so that their sporting lives could be fully retold. This strategy was also an important way by which to achieve a central aim of the study - to give a voice to England's sporting heroines. Anonymity can protect the participants, but it can also deny them "the very voice in the research that must originally have been claimed as its aim" (Parker, 2005: 17).

\section{Data Analysis}

The interviews were transcribed verbatim, with every word spoken written down in the correct order. The qualitative data analysis involved summarising, describing, explaining and theorising the words that had been transcribed. Qualitative data analysis requires going 'into the text seeking to develop, clarify and expand what is expressed in the text' (Kvale, 2009: 192). So, following the interview transcription, which is often considered itself an initial analytical process, the interview transcripts were then subjected to initial coding. This was based on a thematic analysis of the data set. Boyatzis (1998: 1) explains that thematic analysis is 'a way of seeing', while Braun and Clarke 
(2006: 79) describe thematic analysis as 'a method for identifying, analysing, and reporting patterns (themes) within data'. The data was initially divided according to the interview sections: women, national identity, and sporting experience. Each subdivision could then be focussed on more specifically. This meant that each interview in each subdivision was then recoded using more specific and nuanced themes. This procedure took place numerous times with each subdivision of the transcripts. After the themes had been grouped, and further sub-grouped in some instances, the analytical writing-up process could begin. Braun and Clarke (2006: 94) highlight how the extracts in thematic analysis are 'illustrative of the analytic points the researcher makes about the data, and should be used to illustrate/support an analysis that goes beyond their specific content, to make sense of the data, and tell the reader what it does or might mean'.

\section{Warrior Women}

Despite wearing the colours of the UK flag rather than those of the flag of St George, the imaginary figure of John Bull, has often been used to personify Englishness. However, narratives of real women have also contributed to how England is imagined not least those of women such as Queen Boadecia and Queen Elizabeth the First, both hailed for their indomitable fighting spirit and their ability to lead their people as well, if not better, than any man. Indeed, Elizabeth is quoted as having said, 'I know I have the body of a weak and feeble woman, but I have the heart and stomach of a king, and of a king of England too'. It is perhaps unsurprising that women who play sport for England have few qualms about their nation being represented in part through allusion to manifestations of masculine femininity. Before considering what the women had to say about sport in this respect, it is worth recording their thoughts on 'real' as opposed to 'proxy' warriors.

Participants were asked for their opinions about women soldiers serving on the frontline. Kerys and Stacey had no concerns about this.

Kerys Harrop (Football):'If that's what women want to do, you know, and they are capable of doing it for their country so you shouldn't stop them, if they have got the physical capabilities to do it then yeh, you should do it'.

Stacey Francis (Netball): 'I think if a woman wants to, and isn't a detriment to those around her...then you should be given the opportunity'.

Sophie also saw that this could be a positive development. 
Sophie Russell (Rugby Union): 'I think they should be allowed to. Because I think that the world has come to the sat age where there shouldn't be any discrimination now'.

However, she was quick to qualify this assertion.

Sophie Russell (Rugby Union): 'Although I do wonder like on the front like, whether women could possibly lack things like aggression and the ability to make snap decisions under pressure. I think sometimes women can...bring emotions into it too much'.

With this the more widely accepted dichotomy between men and women and their respective socially constructed attributes emerges. This point is further developed by Harriet.

Harriet Millar-Mills (Rugby Union): ...women just aren't as strong as men in the slightest so what's the point, you are putting all the guys at risk by putting a girl in your group, than having a guy'.

In light of these comments, we may be forced to consider the possibility that the women who represent their nation in sport see themselves not only as proxy warriors for the same reason that male athletes are so described but because they are obliged to substitute for and not simply complement true warriors whom some of them believe should not be women. Inevitably, therefore, sport takes centre stage as they reflect on their representation of the nation.

\section{England's Sporting Heroines}

Let's not make it a gender issue. Let's talk about football, not whether someone's male or female. (Hope Powell, former Head Coach of the England women's football team, cited in Adewunmi and Kingsley, 2011: 8).

Despite Hope Powell's protestations, the issue of gender featured strongly in discussions with England's sportswomen. Given that heterosexual discourse posits a certain way of existing for women, including being weak, passive and reliant on men, this operates in contrast to a sporting discourse that requires power and strength (Cox and Thompson, 2000). The female athlete as a paradox has received significant attention from academics (Allison, 1991; Clasen, 2001; Krane et al, 2004). Clasen (2001: 40) summarizes the paradox: 'by placing masculinity and femininity on opposite ends of a dichotomy, women have been excluded from the sporting world, because sports are defined by masculine characteristics'. Not surprisingly then, the majority of the sportswomen who were interviewed highlighted a contrast between the ideology of femininity and the practicality of 
being a sportswoman. The participants maintained that women who are not athletes are more likely to be considered feminine:

Dani Buet (Football): 'Girly girls, proper dress themselves up well, yeh make themselves look good. A lot of makeup, a lot of hair-do. Just really girly, don't do sport.'

Olivia Murphy (Netball): 'People don't associate sporty people with feminine people...You know, they don't necessarily look too feminine on the netball court but take them off it and they are what you would perhaps stereotype as a feminine woman.'

Dani's description is clearly aligned with heteronormative definitions of femininity. The fact that sport is so central to masculine identity in England has led to both participants' rejecting the possibility of being feminine and playing sport. For another participant, the dichotomy of the sexes, and by extension gender, is central to her imagining of sporting bodies:

Katherine Brunt (Cricket): 'In the sports that I play, if you're feminine with the sport you play, you get nowhere...it's all about being masculine because that's the best, apparently'.

For Katherine, masculinity and femininity are described as binary opposites, and sport is linked firmly to masculinity. This is unsurprising. After all, as Wheaton and Tomlinson (1998: 252) explain, 'historically, sport has been so closely identified with men - and masculinity - that the two have become synonymous in many Western societies'. Often success in sport is thus attributed to masculine characteristics, as Katherine confirms here.

Some participants defined sportswomen in terms of their muscular appearance, with muscularity often defined in opposition to femininity:

Charlotte Barras (Rugby): 'All sportswomen, whatever they do, will have muscular definition of some sort...I don't think you can get away with that, and if you aren't like that then you probably aren't training hard enough.'

Kerys Harrop (Football): 'Physically wise...you would probably be quite, not big but muscley, be more athletic than a typical woman.'

The suggestion here is that in order to be successful, and taken seriously, a sportswoman must have a muscular physique; otherwise she cannot be training hard enough. Dworkin (2002: 333) identifies muscles as a paradox of gender for the female athlete, but also notes 'new definitions of 
emphasized femininity that have pushed upward on a glass ceiling of muscularity over time'. Thus, while Kerys appreciates that sportswomen would have a different body shape from a 'typical woman', this shape should still be one that is 'not big'. To be big would read not feminine and possibly, by extension, masculine. Women who exhibit athleticism or masculine characteristics can be perceived as maintaining a position that challenges conceptions of heteronormative femininity, thereby disturbing the woman-feminine-heterosexual matrix. Thus, it is clear that the ideology of woman-feminine-heterosexual constrains how the participants imagine sportswomen.

Of the women interviewed, only a few defined themselves as feminine and even these neglected to describe themselves as feminine within a sporting context. This supports Cox and Thompson (2000: 7) who found that narratives of women football players reveal how they 'conceived and used their bodies, consciously and subconsciously, in multiple ways depending on the context'. Thus:

Stacey Francis (Netball): 'I don't necessarily feel feminine when I am playing and training, [when I] go out with my friends then I definitely make an effort to, I don't know, play up to the girlier side of myself I guess.'

Karen Carney (Football): 'Yeh, I enjoy make up, I enjoy wearing nice...tight fitted...feminine clothes,... but like today I was in the rain for five hours, so is doing my hair a priority? No. And I guess that's where our femininity...gets questioned because we're not in our high heels 24/7.'

These interview extracts highlight the concept of 'selective femininity' (Ross and Shinew, 2008), and the possibility of seeing one's body as being constituted differently by multiple discourses (Cox and Thompson, 2000). Krane (2001) described the 'femininity balancing act' as the way in which women maintain a feminine appearance that conforms to the norms of a heterosexist society, as well as meeting the demands of being an athlete, such as being physically and mentally strong. The way in which the women meet these demands is to treat sport as distinct from the rest of their lives. Viewing their bodies in multiple ways allows them to conform to the demands of being both women and athletes. There appeared to be a form of identity management on the part of the women allowing them to perform heteronormative femininity outside of sport and thereby demonstrating the performative character of gender (Butler, 1990). Negotiating the performance of heteronormative femininity while avoiding masculine behaviours, such as playing sport, becomes problematic for these physically active women, particularly when they define femininity in contrast to, and apart from, sport. They are constantly confronted by the paradox that to be successful in athletics, they must develop characteristics associated with masculinity, which do not align with 
heteronormative femininity. Consequently, they highlight the multiplicity of their identities as sportswomen and women, and the complex, multiple ways in which they see their bodies.

In light of the fact that the participants separate their sporting lives from the idea of being feminine women, they were then asked, 'what does it mean to you to be a sportswoman?' This is where we begin to see the importance of their sporting lives to how they identify themselves.

Serena Guthrie (Netball): 'I always say I don't know what I'd do if I didn't play a sport really, if I didn't play netball...it's such a big part of our lives.'

Claire Purdy (Rugby): 'It's a massive part of what I am...sometimes you forget how big a part it is until you can't do it.'

Claire Rafferty (Football): 'It's...a big part of my life. I think because I have done it for so long. I don't know, it's defined a lot of my life.'

Although the women generally defined themselves as fluid, being able to perform both femininity outside of sport and female masculinity as sportswomen, it is clear that a large part of their identity as they imagine themselves is located within the sporting realm. To a great extent, playing sport defines who they are, and how they wish to be seen. The construction of, and continued reconstruction and performance of, this identity has taken place over time, and given that they perform for England, it would make sense that their sporting identity intersects with both their gendered identity and their national identity.

Endorsing Robinson's (2008) assertion that England exists as England only on the international sports field, sport provides the participants with an avenue to clarify their thinking about and understanding of England as a distinct nation. Some of the sportswomen were explicit in identifying how sport allows them to embody Englishness.

Sophie Bradley (Football): '[Playing for England is] when I recognise it more, because when you are coming up against another country you are like, 'yeh, we are England'.'

For some of the participants, sport represents an environment where they can identify with England whilst outside of sport there remains the possibility of identifying as British, underlining once more the fluid, multiple nature of their identities. According to Robinson (2008: 220), sport is the place where 'Englishness and Britishness no longer merge'. 
Beth Morgan (Cricket): ‘I would say [I'm] British... within my sport that's quite different, l'd be English because I'm playing for England.'

Whilst sport served to clarify national identity in some instances, as well as highlighting the multiple and contextual nature of national identity in others, some of the participants explained how sport serves to increase the importance of a national dimension to their sense of identity.

Claire Allen (Rugby): 'I'm not one of these people that gets the national flag put on my bicep, and I'm not huge on St. Georges day or things like that, but when it comes to playing for England...then I'm hugely, hugely patriotic.'

Here sport undeniably appears central to imagining England and Englishness. We have seen how international sports are forms of 'patriot games', with individuals who are engaged in these activities becoming highly visible 'patriots at play' and active embodiments of the nation (Tuck, 2003). Tuck (1999) found that some (male) international rugby union players develop a strong sense of national sporting identity, in as much as their main source of national pride stems from personal experiences on the rugby field. In the present study, similar findings endorsed the idea of rugby players as 80 minute patriots.

Charlotte Barras (Rugby): 'I definitely feel more English having played for England.'

Harriet Millar-Mills (Rugby): 'I'm not a really a nationally proud person but...You feel part of something to do with England.'

Furthermore, representing England had enabled all of the participants to develop a sense of belonging to the nation and of feeling a 'part' of England, through the opportunity to embody the nation on the field of play.

Edensor (2002: 69) identifies ways in which national identities are '(re)produced by using the metaphor of performance'. As suggested earlier, this concept of performance (Butler, 1990) is a particularly useful metaphor 'since it allows us to look at the ways in which identities are enacted and reproduced, informing and (re)constructing a sense of collectivity' (Edensor, 2002: 69). There are symbolic spaces in which national identities are played out, including sports grounds. Repetitive performances result in memory and identity becoming inscribed on the body so that performing a national identity results in that identity becoming part of the performer. 
To conclude the interviews, the sportswomen were asked to summarize their feelings about playing for England. The following statements demonstrate the importance they attach to their sporting careers:

Tammy Beaumont (Cricket): 'There's nothing really else I want to do with my life, it's that really.'

Claire Purdy (Rugby): 'It will be with me forever, because that's what I am, I'm an England player.'

Evident here are the pride, passion, commitment and dedication invested in the women's sporting careers. They have all chosen this life. They have worked hard and made sacrifices to get to where they are as sporting representatives of England. Claire concludes by saying 'that's what I am'; she is an England women's rugby player, highlighting the way in which gendered, national, and sporting identities overlap and intersect.

\section{Concluding Remarks: Understanding a sportswoman's identity as multiple and fluid}

Central to the foregoing discussion is an acknowledgment of the performative aspect of gender (Butler, 1990) which allows us to understand how sportswomen construct gender, and other identities, in different contexts. For women to be seen as feminine, the participants explained, requires a believable performance of both behaviour and appearance - a feminine woman looks and acts in the right way. This is commonly aligned with heterosexuality, which in itself is important for the nation; women must be feminine, and by implication heterosexual, in order to fulfil their national roles as bearers of children and reproducers of national culture (Yuval-Davis, 1997).

It was clear that femininity was something that the participants believe can be performed depending on different contexts and situations - and sport is an arena which is often considered incompatible with femininity. Cox and Thompson's (2000: 7) initial observations of the women footballers suggested that 'they conceived and used their bodies, consciously or subconsciously, in multiple ways depending on the context'. Findings in this research study support this, in that heteronormative femininity as a construct appeared to be neither embodied at all times or rejected in its entirety by the majority of the participants. Instead, it was something that could be performed, when necessary, in line with the athlete's initial conception of what it means to be a woman (and therefore feminine and heterosexual). This performance, however, was only relevant outside of the international sporting arena. Given that sport is identified as a male-domain that valorizes 
masculine-defined characteristics, it appears obvious that it does not represent an arena in which femininity is appropriate, as the participants explained. However, as sportswomen who represent England at the highest possible level, these women can negotiate the supposed female/athlete paradox (Clason, 2001; Krane 2001) through the performance of different types of femininities which are contextual and highlight the fluidity of gender identities.

The participants in this study are women who actively push the limits of their bodies and also the boundaries of femininity. In this sense, they can be seen as transcendent individuals. Malcom (2003: 1388) states that 'as a result of women's greater participation in sport and society's concomitant growing acceptance of female athleticism, female athletes no longer downplay the traditionally masculine traits of aggression and toughness as they relate to the athletic competition'. This is certainly the case with the women who were interviewed - proud of their dedication, their determination and their toughness in the sporting environment. They understand that being weak and passive will not help them to succeed especially in the male-dominated arena of competitive team sports and, in particular, during international representation. However, as Malcom 2003: 1388) contends, despite this acceptance of a masculine performance, 'they continue to overemphasize traditionally feminine traits'. On the whole, what was most striking were the ways in which the participants described the complexity of their bodies and the performativity of their gendered identities. Moreover, there emerged a comparable argument about the performance of national identity.

As Tuck and Maguire (1999: 27) suggest, international sports can be described as 'patriot games'. Individuals who represent 'their' nations become highly visible embodiments of those nations - they become 'patriots at play'. Following Tuck and Maguire (1999: 26), 'this collection of emotions, attitude and feelings provides some original evidence for viewing national identities "at play" through the eyes of elites sports[wo]men'. The use of 'we' images identifies both insiders and outsiders in everyday speech. Through playing for England, the women feel a strong sense of belonging and of ownership of the nation. In particular wearing the national kit allows the women to actively perform their national identity on the sports field.

Edensor (2002) argues that one of the most powerful forms of popular national performance is to be found in sport. As sporting representatives, these women have a role in the nation that is distinct from those identified by Yuval-Davis and Anthias (1989), and defined by the woman-feminineheterosexual matrix. As Wensing and Bruce (2003) revealed, success in major international competitions seems to open up an avenue for sportswomen to be presented as legitimate national 
representatives, rather than discussed solely in terms of their femininity and heterosexuality. The women who took part in this study embody a version of masculine Englishness during their sports performances. Given that masculinity is relational to femininity, their performance of masculinity is in direct contrast to elements of acceptable, heteronormative femininity. However, where this would not normally be acceptable, nationalism may have the capacity to override gender (Wensing and Bruce, 2003). The women highlighted how their own sense of national identity was heightened during the periods when they were physically representing England. Indeed, international sporting competition is the stage on which they can actively perform their national identity alongside their gendered identity.

To conclude, these sportswomen see themselves as embodiments of England, and their interrelated sporting, national and gendered identities are all essential elements of their sense of self. Essentially, playing sport for the women's national teams is who they are and how they define themselves. However, this alone does not do justice to the complexities and intersectionality of identities and subjectivities. For the participants, national identities are gendered, for example in the ways in which they conceived of (English) national characteristics and traits in masculine ways. Similarly, their gendered identities are national, in the sense that gendered behaviour is normalized in particular (national) societies. What was clear throughout the research process was the performative, multiple and fluid nature of these identities, with both national and gendered identities subject to change dependent upon circumstance. To borrow from Tuck (2003), these women in white (or, for netball, red), and wearing the three lions or the rose are active embodiments of Englishness. They are proud to call themselves English, and represent so much about what a modern vision of Englishness is, and can be. Their reflections demonstrate that in sport, those who represent the nation, and who are the embodiments, heroes, and proxy warriors of England, need not always be men. 


\section{References}

Adewunmi, B. and Kingsley, P. 2011. A whole new ball game. The Guardian. 22 Jun. p.G2 6-11.

Anderson, B. R. O. 2006. Imagined Communities: Reflections on the origin and spread of nationalism (Revised edition). London: Verso.

Bairner, A. 2001. Sport, Nationalism, and Globalization: European and North American perspectives. Albany: State University of New York Press.

Bairner, A. 2015. Assessing the sociology of sport: On nationalism and national identity. International Review for the Sociology of Sport. 50(4-5). pp.375-379.

Bates, L. 2015. Sport's woman problem: The FAs tweet is just the tip of the iceberg. The Guardian, [online] (Last updated 8th July 2015). Available at: <http://www.theguardian.com/football/womensblog/2015/jul/08/sports-woman-problem-the-fastweet-is-just-the-tip-of-the-iceberg> [Accessed on 2 February 2016].

Butler, J. 1990. Gender Trouble: Feminism and the subversion of identity. London: Routledge.

Caudwell, J. 1999. Women's football in the United Kingdom: Theorizing gender and unpacking the butch lesbian image. Journal of Sport \& Social Issues. 23(4). pp.390-402.

Caudwell, J. 2003. Sporting gender: Women's footballing bodies as sites/sights for the (re) articulation of sex, gender, and desire. Sociology of Sport Journal. 20(4). pp.371-386.

Chiang, Y. Bairner, A. Hwang, D. and Chen, T. 2015, Multiple margins: Sport, gender and nationalism in Taiwan. Asia Pacific Journal of Sport and Social Science. 4(1). pp.19-33.

Clasen, P. R. W. 2001. The female athlete: Dualisms and paradox in practice. Women and Language. 24(2). pp.36-41.

Cox, B., \& Thompson, S. 2000. Multiple bodies. International Review for the Sociology of Sport. 35(1). pp.520.

Day, G., \& Thompson, A. (2004). Theorizing Nationalism. Basingstoke: Palgrave Macmillon Ltd. 
Dworkin, S. L. 2002. "Holding back": Negotiating a glass ceiling on women's muscular strength. Sociological Perspectives. 44(3). pp.333-350.

Edensor, T. 2002. National Identity, Popular Culture and Everyday Life. Oxford: Berg.

Flick, U. (2006). Introduction to Qualitative Research. (3rd ed.). London: Sage.

Halberstam, J. 1998. Female Masculinity. London: Duke University Press

Hall, M. A. 1996. Feminism and Sporting Bodies: Essays on theory and practice. Illinois: Human Kinetics.

Hargreaves, J. 1994. Sporting Females: Critical issues in the history and sociology of women's sports. London: Routledge.

Harris, J., \& Clayton, B. (2007). David Beckham and the changing (re)presentations of English identity. International Journal of Sport Management and Marketing, 2(3), pp. 208-221.

Hobsbawm, E. J. 1983. Introduction: Inventing traditions. E. Hobsbawm and T. Ranger, eds. The Invention of Tradition. Cambridge: Cambridge University Press. pp.1-15.

Hobsbawm, E. J. 1990. Nations and Nationalism Since 1780: Programme, myth, reality. Cambridge: Cambridge University Press.

Holmes, M. and Storey, D. 2004. Who are the boys in green? Irish identity and soccer in the Republic of Ireland. In A. Smith and D. Porter, eds. Sport and National Identity in the Post-War World. London: Routledge. pp.88-104.

Jansen, S. C., \& Sabo, D. (1994). The sport/war metaphor: Hegemonic masculinity, the Persian Gulf War, and the new world order. Sociology of Sport Journal, 11(1), pp. 1-17.

Jarvie, G. 1993. Sport, nationalism and cultural identity. In L. Allison, ed. The Changing Politics of Sport. Manchester: Manchester University Press. pp.58-83.

Krane, V. 2001. We can be athletic and feminine, but do we want to? Challenging hegemonic femininity in women's sport. Quest. 53(1). pp.115-133. 
Malcom, N. L. 2003. Constructing female athleticism. American Behavioral Scientist. 46(10). pp.13871404.

McLaren, M. A. 2002. Feminism, Foucault, and Embodied Subjectivity. New York: Suny Press.

McClintock, A. 1993. Family feuds: Gender, nationalism and the family. Feminist Review. 44. pp.6180.

McCrone, D. 1998. The Sociology of Nationalism: Tomorrow's ancestors. London: Routledge.

McGee, D. and Bairner, A. 2011. Transcending the borders of Irish identity? Narratives of Northern nationalist footballers in Northern Ireland. International Review for the Sociology of Sport. 46(4). pp.436-455.

Messner, M. A. and Sabo, D. F. 1990. Introduction: Toward a critical feminist reappraisal of sport, men, and the gender order. In M. A. Messner and D. F. Sabo, eds. Sport, Men, and the Gender Order. Champaign: Human Kinetics. pp.1-16.

Nagel, J. 2008. Gender, sexuality, and nationalism. In G. H. Herb and D. H. Kaplan, eds. Nations and Nationalisms: A global historical overview: Volume 1 (1770-1880). California: ABC Clio, pp.901-911.

Orwell, S. and Angus, I. 1970. The Collected Essays, Journalism and Letters of George Orwell (volume IV): In front of your nose. Harmondsworth: Penguin.

Parker, I. (2005). Qualitative Psychology: Introducing radical research. Maidenhead: Open University Press.

Pettman, J. J. 1996. Worlding Women: A feminist international politics. Sydney: Allen Unwin.

Robinson, J. 2008. Tackling the anxieties of the English: Searching for the nation through football. Soccer and Society. 9(2). pp.215-230.

Ross, S. R. and Shinew, K. J. 2008. Perspectives of women college athletes on sport and gender. Sex Roles. 58(1). pp.40-57.

Smith, A. and Porter, D. 2004. Introduction. In A. Smith and D. Porter, eds. Sport and National Identity in the Post-War World. London: Routledge. pp.1-9. 
Theberge, N. (1994). Toward a feminist alternative to sport as a male preserve. In S. Birrell, \& C. L. Cole (Eds.), Women, Sport and Culture. Champaign: Human Kinetics, p. 181-192.

Tuck, J. 2003. The men in white: Reflections on rugby union, the media and Englishness. International Review for the Sociology of Sport. 38(2). pp.177-199.

Tuck, J. and Maguire, J. 1999. Making sense of global patriot games: Rugby players' perceptions of national identity politics. Football Studies. 2(1). pp.26-54.

Wensing, E. H. and Bruce, T. 2003. Bending the rules. International Review for the Sociology of Sport. 38(4). pp.387-396.

Wheaton, B. and Tomlinson, A. 1998. The changing gender order in sport? Journal of Sport \& Social Issues. 22(3). pp.252-274.

Whitehead, A., Connolly, C., Carter, E. and Crowley, H. 1993. Nationalisms and National Identities Editorial. Feminist Review. 44(1). pp.1-2.

Willis, P. 1994. Women in sport in ideology. In S. Birrell and C. L. Cole, eds. Women, Sport and Culture. Champaign: Human Kinetics. pp.31-46.

Yuval-Davis, N. 1997. Gender \& Nation. London: Sage Publications.

Yuval-Davis, N. and Anthias, F. eds., 1989. Woman-nation-state. New York: St. Martin's Press. 